\title{
Comparison of Water Use Efficiency in Alfalfa Using Water and Waste Water
}

\section{Rahim Alimohammadi Nafchi}

Agricultural Engineering Research Department, Chaharmahal and Bakhtiari Agricultural and Natural Resources Research and Education Center, AREEO, Shahrekord, Iran

Email: Nafchi38@gmail.com

How to cite this paper: Nafchi, R.A. (2016) Comparison of Water Use Efficiency in Alfalfa Using Water and Waste Water. Journal of Agricultural Chemistry and Environment, 5, 191-199.

http://dx.doi.org/10.4236/jacen.2016.54020

Received: September 7, 2016

Accepted: October 31, 2016

Published: November 3, 2016

Copyright $\odot 2016$ by author and Scientific Research Publishing Inc. This work is licensed under the Creative Commons Attribution International License (CC BY 4.0).

http://creativecommons.org/licenses/by/4.0/ c) (i) Open Access

\begin{abstract}
Growth of cultural and economic level of societies has caused conversion of villages to cities and establishment of wastewater treatment plant in cities. Wastewater treatment plants discharge significant amounts of wastewater into natural waterways and their output at the most critical time (the hottest day that crop water need reaches to maximum due to physiological conditions) reaches to the highest amount. Hence, with regard to permanent and accessible wastewater and study on performance and production of forage per water or wastewater consumption unit, the research project was performed in form of statistical plan of totally random blocks with four treatments in three replications during three years. The results indicate that function of forage at the third year of project implementation has increased than the first and second years. Treatments 2 and 4 (the treatments to use wastewater) had greater function than treatments 1 and 3 (treatments that have irrigated with well water), found with significant difference. In average, function of forage (dry and wet) in treatments irrigated with wastewater than the treatments irrigated with well water has been greater to 37 and 32 percent regardless of consumption amount. Water consumption efficiency in the treatments to use wells water and wastewater equals to 0.867 and $1.09 \mathrm{~kg}$ production of dry hay per cubic meter of water or wastewater.
\end{abstract}

\section{Keywords}

Alfalfa, Water, Wastewater, Water Consumption Efficiency

\section{Introduction}

Water consumption efficiency is used for optimal and stable use of water resources and comparison of utilization of water at various periods of time and places. Nowadays, due to water scarcity and increasing demand for water consumption, use of unconventional 
water is inevitable. Drinking water and household water supply has been regarded as one of the priorities of the communities, which ultimately they should be produced after consumption regarding the standards of energy ministry and entered into the natural channels. In most of regions especially arid and semi-arid regions, wastewaters can be targeted in agriculture consumption in hot seasons of year and enter into aquifers via feeder systems in cold seasons of year and then underground waters are consumed via the existing mechanisms in the seasons which are required. Optimal use of this cheap water resource (wastewater) can reduce the challenge to water demand in the region. The main solution is to increase water consumption efficiency by operation of modern irrigation systems, correct operation of planting and harvesting, use of modified seeds, timely control for pests and diseases, apply integrated irrigation management together with precise operation of irrigation plan at farm. Use of Municipal Wastewater Treatment Plant is considered a method for optimal water consumption. The treatments irrigated with wastewater than ordinary water in Morocco have been greater product function [1]. Shayegan concluded that harvesting of alfalfa from farms irrigated with wastewater has been greater than the crop irrigated with well water to 20 to 40 percent [2]. Use of Municipal Wastewater Effluent can be considered a secure and acceptable method for water supply in all the countries worldwide especially in arid regions, followed by other benefits such as improvement in environmental conditions and supply of nutrients for crops in addition to reduction in water scarcity [3]. A number of researchers in Saudi Arabia have proved that use of Wastewater Treatment Plant for irrigation of various products causes increased function at surface unit than ordinary water treatment [4]. Function of forage treatment irrigated by sewage (75 percent of sewage and 25 percent tap water) has been more than other treatments [5]. Use of unconventional waters for irrigation of agricultural products in arid regions is of great importance, so that reuse of Wastewater Treatment Plant by applying specific management operation can be considered as a technology at arid regions and plant water need supply can be supplied by applying irrigation management [6]. The water consumption efficiency for grain production in North America was reported $1.4 \mathrm{~kg}$ per cubic meter of water consumption [7]. According to a study conducted in Darab County, water consumption efficiency for wheat and corn equals to 0.48 and $0.60 \mathrm{~kg}$ per consumption of per cubic meter of water [8]. Function of grass sorghum in control treatment with 100 percent irrigation and treatment with 60 percent water need has been 1.28 and $1.78 \mathrm{~kg}$ per cubic meter of consumption water in Sistan [9]. Water consumption efficiency for wheat seeds, tubers, sugar beet, potatoes, corn and alfalfa equals to $0.73,4.56,2.18,5.58$ and $0.71 \mathrm{~kg}$ of product per cubic meter of water and average weight of water consumption efficiency equals to $1.38 \mathrm{~kg} / \mathrm{m}^{2}$ water [10]. Average water consumption efficiency to produce corn (digit 704 and 604) at Marvdasht equals to 0.7 $\mathrm{kg}$ per consumption of one cubic water [11]. According to a study on southwest of Shahrekord city using water and wastewater treatment in irrigation of corn, it was concluded that efficiency of water consumption in the treatment for use of wastewater and water has equaled to 3.37 and $4.81 \mathrm{~kg}$ per cubic meter water consumption [12]. In Joo- 
par research Station (Kerman, Iran), in irrigation of cotton ball with water and wastewater, it has been announced that it can save water consumption for $1800 \mathrm{~m}^{3}$ per hectare and increase water consumption efficiency to 78.9 percent [13]. A number of researchers at western south of Nigeria claimed that water consumption efficiency in irrigation treatment with wastewater has been greater than the treatment with water [14]. Shahrekord with population over 140 thousands persons and daily consumption of 170 liter per person each day and conversion coefficient of 70 percent has the wastewater over Seventeen thousand cubic meters per day, which this is equivalent to $196 \mathrm{l} / \mathrm{s}$ during year. This output is not the same during different days of year, but at critical periods of year that demand for water consumption for agriculture consumption is high, rate of wastewater intensifies and reuse of wastewater at Wastewater Treatment Plant becomes the most beneficial way to avoid environment pollution and supply a percent of water needs. Alfalfa acreage in Chaharmahal and Bakhtiari Province is over 15,000 hectares with an average yield of $10,850 \mathrm{~kg}$ per hectare. Farmers engage in cultivation and irrigation via surface method (furrow and basin) with time periods of 10, 12 and 14 days regarding the current irrigation round. To improve the sustainable management of water demand, culture of optimal water consumption should become $\mathrm{c}$ universal and individual in the community should make huge effort to increase water consumption efficiency and demand management of water consumption. Nowadays, in most crops, the cost price for the production of product from income due to low efficiency and water consumption efficiency is greater. Hence, with regard to real value of water, energy costs and other costs, water consumption efficiency should increase in order that the agriculture sector enables to compete with other economic sectors of society and status

of food security improves in the society. Calculation of water consumption efficiency for each product especially dominant products is required at region; with regard to crisis on water scarcity and production of domestic wastewater treatment plants, use of wastewater is inevitable, under which water and wastewater consumption efficiency in alfalfa harvest were calculated and analyzed.

\section{Materials and Methods}

This study was performed during three years at the Chartakhteh research station of Shahrekord, Chaharmahal and Bakhtiari province, at geographical area $50^{\circ} 56^{\prime} 3.5^{\prime \prime}$ East longitude and $32^{\circ} 17^{\prime} 54.5^{\prime \prime}$ north latitude at an altitude of 2097 meters. The climatic status of this station is based on Köppen-Geiger climate classification, cold climate with hot and arid summers, and Karimi division, semi-humid climate with mild summers and very cold winters. The average annual precipitation of $295 \mathrm{~mm}$, average daily temperature of 12.2 degrees Celsius, average relative humidity 42 percent and $1710 \mathrm{~mm}$ evaporation per year. Water supply stations, deep wells (two rings) with discharge of 35 liters per second that is unrestricted from salt, belonged to the group of C1 S1. Soil texture on the region for project implementation is of the heavy soils (clay loam). Dimensions of terraces have been $3.5 \times 4.5$ meter that each terrace had 2 meter distance with the adjacent terrace at related repetition and 2 meter distance with terrace at next repe- 
tition. This experiment was performed in form of statistical project of randomized complete block design with four treatments and three repetitions. Irrigation treatments using two water resources, well water and municipal wastewater treatment plant are as follow:

Treatment 1: irrigation with well water and control treatment.

Treatment 2: irrigation with municipal wastewater treatment plant and control treatment.

Treatment 3: irrigation with well water to the amount of required water.

Treatment 4: irrigation with municipal wastewater treatment plant to the extent of required water.

Water volume and input wastewater to each terrace at each stage measured via two-inch meters counters. At the end of each cutting, the yield of product was calculated. To calculate the amount of required water of treatment 3 and 4, firstly amount of evaporation was calculated via Penman-Monteith Equation using Statistics of synoptic station at Shahrkord located at 2061.4 meters height and software Cropwat. To apply various irrigation treatments, the well water of station for plots 1 and 3 and municipal wastewater treatment plant for plots 2 and 4 were used. Water consumption efficiency is obtained through the production function dividend by amount of consumed water. Data analysis was made via software SAS, comparison of means via Duncan Multiple Range Test (MRT), drawing diagrams via software Excel and preparing tables via software Word.

\section{Discussion and Conclusion}

Compound variance analysis of dry forage yield during project operation years indicates that there is no significant difference between repetitions, but there is a significant difference between various treatments and mutual effect of treatment at one percent of f-test during project operation years (Table 1). Comparison of means of wet alfalfa yield during various years at 5 percent level of Duncan's new multiple range test (MRT)

Table 1. Compound variance analysis of alfalfa yield (kg per hectare).

\begin{tabular}{cccc}
\hline Variation resources & Degrees & & \multicolumn{2}{c}{ Average of squares } \\
\cline { 3 - 4 } freedom & & Dry yield & Wet yield \\
Repeated & 2 & $132,970.2^{\text {ns }}$ & $2,732,392.9^{\text {ns }}$ \\
Year & 2 & $47,7041,699.4^{* *}$ & $2,503,364,479.6^{* *}$ \\
Error & 4 & $558,950.1$ & $2,607,691.3$ \\
Treatment & 3 & $22,632,001.0^{* *}$ & $192,411,101.2^{* *}$ \\
Interaction between treatments in years & 6 & $5,170,099.4^{* *}$ & $38,573,727.8^{* *}$ \\
Error & 18 & $897,317.4$ & $4,614,913.7$ \\
Total & 35 & & \\
\hline
\end{tabular}

${ }^{*}$ Significant difference at 1 percent level. ${ }^{*}$ Significant difference at 5 percent level. ${ }^{\text {ns }}$ Not significant. 
has significant difference. Treatments 2 and 4 have more yield, but there is no significant difference on yield of treatments 2 and 4 (29,324 and 28,992 $\mathrm{kg}$ per hectare). Comparison of mean of dry yield during various years of project operation indicates that yield at the third year than the first and second years is greater and difference has been significant at 5 percent level of Duncan's new multiple range test (MRT); further comparison of mean of dry yield between various treatments indicates a significant difference at 5 percent level of Duncan's new multiple range test (MRT) in such a way that treatments 2 and 4 have greater yield (Table 2). Comparison of means of water type on wet forage yield regardless of amount of consumption indicates that mean of treatments for use of domestic wastewater treatment plants has greater yield, found with significant difference. Comparison of mean of dry yield regarding irrigation water during project operation time indicates that forage yield in the treatments for use of ordinary water and wastewater has not witnessed with significant difference, but yield of treatments for use of wastewater has greater yield (Table 3). Changes in dry and wet yield of treatments during project operation time indicate increased yield of treatment 2 and 4 than treatment 1 and 3 during project operation years. Comparison of mean of dry plant yield at various treatments during consecutive years of project operation indicates that dry yield of treatments has significant difference at 5 percent of Duncan's new multiple range test (MRT) in such a way that the treatments to use wastewater 2 and 4 have further dry yield (Table 2).

Table 2. Comparison of mean of dry and wet yield of alfalfa (kg per hectare) at Chahartakhteh research station (1998-2003).

\begin{tabular}{ccc}
\hline Year & Wey yield & Dry yield \\
\hline 79 & $1111.0 \mathrm{c}$ & $3592.5 \mathrm{c}$ \\
80 & $24531.2 \mathrm{~b}$ & $9361.3 \mathrm{~b}$ \\
81 & $39973.5 \mathrm{a}$ & $16187.8 \mathrm{a}$ \\
Treatments & Wey Yield & Dry Yield \\
1 & $20367 \mathrm{~b}$ & $7959.6 \mathrm{~b}$ \\
2 & $29324 \mathrm{a}$ & $11304.3 \mathrm{a}$ \\
3 & $22138 \mathrm{~b}$ & $8815.0 \mathrm{~b}$ \\
4 & $28992 \mathrm{a}$ & $10776 . \mathrm{a}$ \\
\hline
\end{tabular}

${ }^{*}$ Means within column that have the same letter are not significantly different at 5 percent level (DMR test).

Table 3. Comparison of consumed water resource during project operation years (1998-2003).

\begin{tabular}{ccc}
\hline Water resources & Wet yield & Dry yield \\
\hline Normal water & $21252.5 \mathrm{~b}$ & $8387.6 \mathrm{a}$ \\
Wastewater & $29158 \mathrm{a}$ & $11040.4 \mathrm{a}$ \\
\hline
\end{tabular}

${ }^{*}$ Means within column that have the same letter are not significantly different at 5 percent level. 
The results from comparison of mean of dry and wet forage in Table 2 indicate that there is a significant difference between yield of treatments 1 and 3 (well water) and yield of treatments 2 and 4 (use of wastewater). Use of wastewater causes increased dry and wet forage yield. Function of forage in irrigation treatments with wastewater and ordinary water indicates that irrigation with wastewater has greater function, found with significant difference. Results from this research are consistent with the results from research by Valinejad, Kuhpaei, Hossain, Hamori and Luis Santos.

Water consumption volume has been 17333 liter per hectare at each year, yet water consumption volume at plots 3 and 4 which has been calculated relating to the required water has been 14895 liter per hectare at each year (Table 4). Treatments 2 and 4 have greater yield, found with significant difference with other treatments (Table 4). Treatments 1 and 2, irrigation with water and wastewater consumption equaled to $17333 \mathrm{~m}^{3}$ per hectare in each year has different dry and wet product production yield, in such a way that water consumption efficiency in treatment 1 and 2 equals to 0.75 and $0.994 \mathrm{~kg}$ alfalfa production per cubic water consumption. The treatment for use of wastewater has higher water consumption efficiency and yield than treatment 1 (Table 4). Treatments 3 and 4 of irrigation based on the required water using well water and Wastewater Treatment Plant indicate that dry and wet product yield at treatment 4 is greater than treatment 3. As a result, efficiency of water consumption yield at treatment 3 and 4 equals to 1.01 and $1.18 \mathrm{~kg}$ dry alfalfa per one cubic water consumption so that treatment 4 has greater yield and less water consumption (Table 4 and Figure 1).

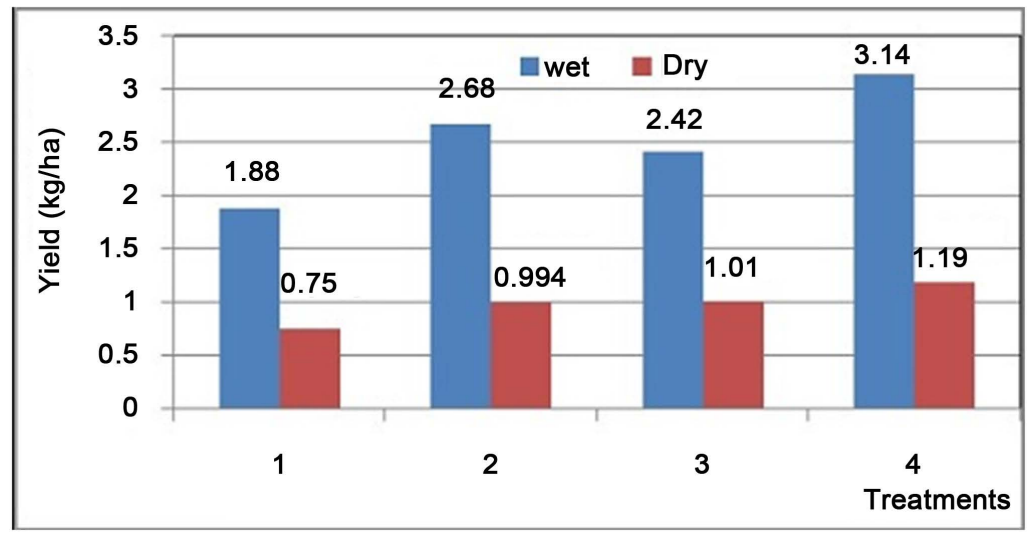

Figure 1. Water consumption efficiency.

Table 4. Yield of water consumption production and efficiency at 2003.

\begin{tabular}{|c|c|c|c|c|c|}
\hline \multirow{2}{*}{ Treatments } & \multicolumn{2}{|c|}{ Yield (kg/ha) } & \multirow{2}{*}{$\begin{array}{c}\text { Water } \\
\text { consumption } \\
\left(\mathrm{m}^{3} / \mathrm{ha}\right)\end{array}$} & \multicolumn{2}{|c|}{ WUE $\left(\mathrm{kg} / \mathrm{m}^{3}\right)$} \\
\hline & Wet & Dry & & Wet & Dry \\
\hline 1 & 32593 & 12922 & 17333 & 1.88 & 0.75 \\
\hline 2 & 46512 & 17226 & 17333 & 2.68 & 0.994 \\
\hline 3 & 36000 & 15009 & 14895 & 2.42 & 1.01 \\
\hline 4 & 46724 & 17835 & 14895 & 3.14 & 1.19 \\
\hline
\end{tabular}




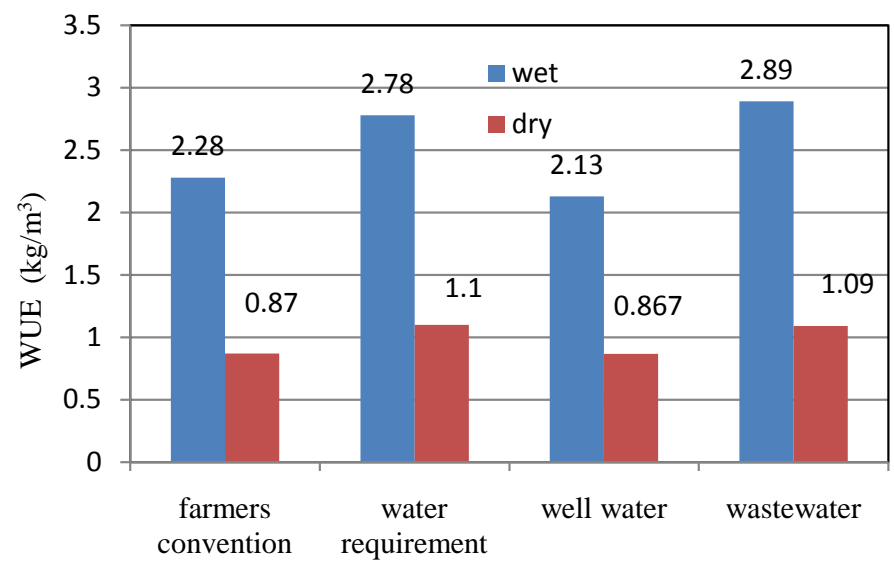

Figure 2. Yield of dry and wet alfalfa production.

Table 5. Water and wastewater consumption efficiency and production in 2003.

\begin{tabular}{|c|c|c|c|c|c|}
\hline \multirow{2}{*}{ Treatments } & \multicolumn{2}{|c|}{ Yield (kg/ha) } & \multirow{2}{*}{$\begin{array}{c}\text { Water } \\
\text { consumption } \\
\left(\mathrm{m}^{3} / \mathrm{ha}\right)\end{array}$} & \multicolumn{2}{|c|}{ WUE $\left(\mathrm{kg} / \mathrm{m}^{3}\right)$} \\
\hline & Wet & Dry & & Wet & Dry \\
\hline Well water & 34,296 & 13,965 & 16,114 & 2.13 & 0.867 \\
\hline Wastewater & 46,618 & 17,530 & 16,114 & 2.89 & 1.09 \\
\hline
\end{tabular}

Table 6. Water consumption efficiency and production in 2003.

\begin{tabular}{|c|c|c|c|c|c|}
\hline \multirow{2}{*}{ Treatments } & \multicolumn{2}{|c|}{ Yield (kg/ha) } & \multirow{2}{*}{$\begin{array}{c}\text { Water } \\
\text { consumption } \\
\left(\mathrm{m}^{3} / \mathrm{ha}\right)\end{array}$} & \multicolumn{2}{|c|}{ WUE $\left(\mathrm{kg} / \mathrm{m}^{3}\right)$} \\
\hline & Wet & Dry & & Wet & Dry \\
\hline Farmers convention & $39,552.5$ & $15,074.1$ & 17,333 & 2.28 & 0.87 \\
\hline Water requirement & 41,362 & 32,845 & 14,895 & 2.78 & 1.1 \\
\hline
\end{tabular}

The results from yield of treatments based on type of consumed water have been proposed in Table 5. Wet yield, dry yield, water consumption efficiency are greater in the treatments in which wastewater has been used than the treatments which have been irrigated with well water, in such a way that water consumption efficiency in the treatments irrigated with well water and wastewater equals to 0.867 and $1.09 \mathrm{~kg}$ alfalfa production per one cubic water or wastewater consumption and 2.13 and $2.89 \mathrm{~kg}$ alfalfa production per one cubic water or wastewater consumption. If the water type is discarded, the treatments that their amount of water or wastewater had been calculated based on the amount of the required water had wet yield, dry yield and greater water consumption efficiency (Table 6, Figure 2).

\section{Conclusion}

Use of domestic wastewater treatment plants at surrounding areas of municipal wastewater treatment plants due to shortage of irrigation water, high cost of water supply, secure wastewater production with easy access and transfer of produced wastewaters have been regarded as the major factors for reuse of wastewaters which are effective due 
to have nutrients in production and yield of crops. Obtained results indicate that the treatments irrigated with municipal wastewater treatment have better yield and more production of dry and wet alfalfa than the treatments which have used well water for irrigation. Water consumption efficiency is greater in wastewater than well water treatments. Water consumption efficiency in the treatments for use of well water and wastewater equaled to 0.867 and $1.09 \mathrm{~kg}$ dry alfalfa production per one cubic water and wastewater consumption and equaled to 2.13 and $2.89 \mathrm{~kg}$ wet alfalfa production per one cubic water and wastewater consumption. The treatments that their water or wastewater amount had been calculated based on amount of the required water had more wet and dry yield and water consumption efficiency than the treatments irrigated with water or wastewater amount.

\section{Acknowledgements}

I acknowledge the effort of my colleagues in this research center especially Engineer Khodadadi for his assistance in the field and engineer Farzan in the soil sample analyses.

\section{References}

[1] Hamouri, B.E. and Handouf, A. (1996) Use of Wastewater for Crop Production under Arid and Saline Conditions: Yield and Hygienic Quality of the Crop and Soil Contaminations. Water Science and Technology, 33, 327-334. http://dx.doi.org/10.1016/0273-1223(96)00435-0

[2] Shayegan, C. (1999) Experiences of a Selected Field Irrigation with Treated Wastewater. Iranian National Committee on Irrigation and Drainage Issue, 28, 53-60.

[3] Tavakoli, M. and Tabatabai, M. (1999) Irrigation with Treated Wastewater. Proceedings of the International Conference on Environmental Aspects of Using Wastewater in Irrigation, Ministry of Energy, National Committee on Irrigation and Drainage, Tehran, 11 December 1999, 26 p.

[4] Hossain, G. and Saati, A.J.A. (1999) Wastewater Quality and Its Reuse in Agriculture in Saudi Arabia. WSTA Fourth Gulf Water Conference, 123, 241-251. (Desalination) http://dx.doi.org/10.1016/s0011-9164(99)00076-4

[5] Berki, H. and Rezvani, A.S. (2001) Effects of Irrigation Water from Domestic Sewage Treatment Plant on the Quality and Quantity of Forage Millet. Magazine Study Ways to Deal with the Water Crisis, 468-455.

[6] Pereira, L.S. and Oweis, T. (2002) Irrigation Management under Wader Water Scarcity. Agricultural Water Management, 57, 175-206. http://dx.doi.org/10.1016/S0378-3774(02)00075-6

[7] Tolk, J.A. and Howell, T.A. (2003) Water Use Efficiencies of Grain Sorghum Grown in Three USA Southern Great Plains Soils. Agricultural Water Management, 59, 97-111. http://dx.doi.org/10.1016/S0378-3774(02)00157-9

[8] Soleimani, H. and Hasanli, A.S. (2008) Calculate the Cost, Efficiency and Added Value for Major Crops in the Arid Region Academy. Iran Agricultural Knowledge, 5, 45-60.

[9] Kaykhaee, F., Ganji, N., Farzanju, M., Keykha, Gh., Saghafi, K. and Keykha, D. (2010) Study on Effect of Water Scarcity on Water Use Efficiency of Forage Sorghum Crop in the Sistan Region. Journal of Water in Agriculture (b), 24, 41-49. 
[10] Hydari, N. (2011) Performance Index to Determine and Evaluate the Use of Crops in the Country under the Management of Agriculture. Water Management and Irrigation Journal, 1, 43-57.

[11] Mohammadi, H., Bostani, F. and Asadi, E. (2011) Water Use Efficiency and Profitability Analysis of Different Corn Hybrids Evaluated in the Region. Agricultural Economics and Development, the Nineteenth Year, Number 74, 129, 147.

[12] Aalinejadian, A. and Maleki, A. (2013) Evaluation of Water Use Efficiency and Yield of Maize in Urban Wastewater in an Area with Cold Dry Weather. The First National Conference on the Challenges of Water Resources, Agriculture, Irrigation and Drainage Association of Iran, Islamic Azad University, Isfahan, 24 February 2013, 8 p.

[13] Zonemat-Kermani, M., Asadi, R. and Dehghani-Sanij, H. (2015) The Effect of Different Amounts of Wastewater on Cotton Yield with Drip Irrigation. Journal of Water in Agriculture, 29, 74-63.

[14] Abegunrin, T.P., Awe, G.O., Idowu, D.O. and Adejumobi, M.A. (2016) Impact of Wastewater Irrigation on Soil Physico-Chemical Properties, Growth and Water Use Pattern of Two Indigenous Vegetables in Southwest Nigeria. CATENA, 139, 167-178.

http://dx.doi.org/10.1016/j.catena.2015.12.014

\section{Submit or recommend next manuscript to SCIRP and we will provide best service} for you:

Accepting pre-submission inquiries through Email, Facebook, LinkedIn, Twitter, etc. A wide selection of journals (inclusive of 9 subjects, more than 200 journals)

Providing 24-hour high-quality service

User-friendly online submission system

Fair and swift peer-review system

Efficient typesetting and proofreading procedure

Display of the result of downloads and visits, as well as the number of cited articles Maximum dissemination of your research work

Submit your manuscript at: http://papersubmission.scirp.org/

Or contact jacen@scirp.org 